\title{
International Organizations, Institutions and the Indigenous people
}

https://doi.org/10.21272/sec.5(2).81-95.2021.

Dr. Debesh Bhowmik, ORCID: https://orcid.org/0000-0002-0293-1066

Honorary Research Professor, Lincoln University College, Malaysia

\begin{abstract}
The paper explains the role of international institutions and international organizations which usually have been working for the rights, freedom, survival, livelihood and financial assistances of the indigenous people since the inception of peoples' democracy in India and abroad. The possible policies that can be helpful for indigenous people in the present world have been also discussed here. How do international financial institutions assist the indigenous people to maintain their social livelihood through their projects, how UNFCCC, IIPFCC, GFC, IAITPTF, IWGIA, IPLP have been working with tribal people in climate change, forest policies and assisting laws and other social and economic activities have been discussed in this paper. Generally, UNFCCC recommended policies on the victimized tribes due to climate change calamities. Since 2019, GFC with their 99 indigenous and non-indigenous member groups from 65 countries have been supporting the struggles of indigenous people by bringing their views, positions and proposals to the forefront of local, national, and global forest-related decision-making processes. IAITPTF has been protecting the tribal people of tropical forest areas in Africa and Latin America. IWGIA in collaboration with ECOSOC have been working for indigenous people in Amazon Basin, Asia, Africa, Latin America and Russia enacting of REDD+ and rights in forests in context of climate change. Since 1999, IPCB protects tribal genetic resources, knowledge, culture, human right and negative effects of biotechnology. The IITC has been organizing tribes to participate in local, regional, national and international events on their survival through human rights agendas. IPACC which consists of 135 tribal organisations in 20 African countries, has been fighting for human rights, legal rights and social inclusion of tribes. The World Bank and African Development Bank took various policies and projects for financing tribal development such as OD4.20. UNDP, ILO and IITC nourish the human rights in the process of development in education and health of tribal people.
\end{abstract}

Keywords: Indigenous people, organizations, institutions, ILO, UNFCCC, IWGIA.

JEL Classification: D63, F13, F33, F53, F59, J15, L31, O19, P37, Q50.

Cite as: Bhowmik, D. (2021). International Organizations, Institutions and the Indigenous people. SocioEconomic Challenges, 5(2), 81-95. https://doi.org/10.21272/sec.5(2).81-95.2021.

Received: 21.03 .2021

Accepted: 15.05 .2021

Published: 25.06.2021

Copyright: (C) 2021 by the author. Licensee Sumy State University, Ukraine. This article is an open access article distributed under the terms and conditions of the Creative Commons Attribution (CC BY) license (https://creativecommons.org/licenses/by/4.0/).

\section{Introduction}

In 1966, International Convenant on Economic Social and Cultural Right (ICESCR) in their Article 11 passed "right to food" to ameliorate hunger and to keep up living. UNESCO agreed with it. Even, UN Declaration on the rights of indigenous peoples in article 20 and 26 and ILO Convention 169 have passed these rights. FAO also recognized the indigenous peoples to have the right to food along with access to natural resources, intellectual property rights and environment(Knuth,2009).Ensuring Right to food for the indigenous people in both national and international levels is not a basic concept but for implement which require close coordination ,co-operations, consensus, vision for sustainable goals among international institutions in the category of law, governance, 
finance in one hand and indigenous organizations and communities on the other hand. Hopefully stated that the dealing of Indigenous People of Africa Coordinating Committee (IPACC) with UNESCO, MEA of IPCC, recommendations of COP19 showed successful multilateral co-operation of international institutions on the issues of traditional knowledge of indigenous people for positive aspects of sustainable development. Without empowering indigenous women and men as development and climate change actors, without giving social justice and equal scope for livelihood through the provisions of institutions, objectives of the sustainable development will be meaningless, uneconomic and unethical. Institutional framework for participation of tribal population in economic development work is vital and inclusive growth driven target which might transform societal evolutionary process. It is a core and fundamental issues of the globe that in which laws, social and economic system with selected governance can be fitted for inclusive growth process if the indigenous people are included in all the sectors of the economy where provision of institutions is the primary agenda and multilateral coordination is the secondary agenda which enables the sustainable development a success.

The paper has been prepared with the help of websites of [i] The Indigenous Peoples of Africa Coordinating Committee, [ii] The Tribal Cooperatives Marketing Development Federation of India,[iii] The International Indigenous People Forum on Climate Change,[iv]International Indian Treaty Council, [v] Indigenous Peoples Council on Bio-colonialism,[vi]The Centre for World Indigenous Studies,[vii] The Indigenous Peoples Law and Policy, [viii] International Work Group for Indigenous Affairs,[ix] Global Forest Coalition, [x] International Alliance of Indigenous and Tribal Peoples of Tropical Forests,[xi] African Development Bank, [xii] The World Bank, [xiii] United Nations Framework Convention on Climate Change, [xiv] International Labor Organization, [xv] United Nations Development Programme and so on. The paper also utilized the GFC Annual Report-2019 and IWGIA Annual Report-2019 and other relevant studies relating to this theme to include necessary concepts, observations, analysis and reviews.

\section{Some important studies}

Debnath (1992) claimed that during the traditional process of Indian democracy of political system from Central Government to Panchayat level in decentralizing power to ameliorate poverty and inequality, the domination of one class of tribe over other tribal communities is still hampering the tempo of development of indigenous people.

Sarmah (2007) described the role of NGO in tribal development in Assam focusing on efficiency and effectiveness of the voluntary agencies which emphasis the empowerment of women, livelihood, health, legal aid, credit facilities and vocational training etc.

Miller (2008) explained that in August 2007, American Indian nations, Canadian First nations, New Zealand Maori Iwis and Australian Aborigine groups signed a treaty to engage in international economic activities. The treaty served the valuable purpose of helping indigenous groups signing treaties with each other to coordinate their efforts to work together on mutual benefit and to strengthen their interrelated bonds. American Indian nations and indigenous groups everywhere can use these treaties to empower the economic, education, health of the people by increasing resources.

Nanjunda and Dinesha (2011) studied that many NGOs have been working on tribal health in India and abroad which could come close contact with tribes to understand their health status easily in which NGO need to know the background of culture, traditional knowledge and other livelihood patterns for better outcome of their services. NGOs in Karnataka have been serving in increasing human development indices of tribes in agricultural sector. NGOs need more funds, government support, proper training, and skilled staffs. NGO-government collaboration can do MDG targets for tribal health where tribes are required gainful awareness applying door to door survey, running clinic and health training for them to cure minor diseases.

Mahapatra (2015) argued that the traditional institutions like self-government which exist in North East region should be transformed into inclusive growth process and requires successive reform. In this situation, India government under sixth schedule can recognize these local autonomies in the equal access service provision through state where democratic institution empowers peoples' participation that can also be capable of gender equality to indigenous people. 
Babar (2016) clearly explained that globalization and liberalization affect inversely to the development process of indigenous people in India because of unequal distribution of assets, income, credit, power, knowledge and skill. Therefore, special programme and policies are necessary between haves and have nots in the course of globalization which calls for a new development model.

Bhowmik (2017) argued that the institutional role matters to search the origin of indigenous people, their recognition, identity, to provide their rights and to formulate policies for maintaining their livelihood so that planning process can endeavour to form from a schedule of actions inclusively.

Gawas (2017) scrutinized the fifth schedule of the Indian constitution in Goa in the areas of land alienation, money lending, displacement, and industrial development projects which adversely affected tribes of Goa and failed to commit proper achievements.

Thamminaina (2018) explained the activities of NGO in comparison with governmental programme of tribal development. The author felt that the NGO can act as a bridge between government agencies and the people by playing an active advocacy role which can implement the projects successfully and produce better results. The NGOs act as safety net in the process of development.

Mander (2020) concludes that darkness and protective laws of tribal policy in India failed to achieve genuine financial devolution and obviously the educational policy destroyed moorings of tribal culture. The study recommended that India needs radical tribal laws for development which demands self-government for tribal communities and the perils of tribal identity and survival remain as real as ever.

\section{Objective of the article}

In this article author endeavors to explain the plausible functions, objectives and implements of international organizations and institutions by which the indigenous people usually get benefits to their rights, access of land and property, activities of living in forests and forests localities, employment opportunities, health and educational rights, and basic necessities as well as human rights and legal facilities around the globe.

\section{International Institutions and Indigenous people}

\subsection{International Labour Organization (ILO)}

The International Labour Organization (ILO) was the first international organization to address indigenous and tribal issues and signal the need for cooperation and international attention. It has been working to protect and promote the rights of indigenous and tribal peoples since the early 1920s. In 1957 under article 107, ILO developed two international instruments relating exclusively to indigenous and tribal peoples. In 1989, International Labour Organization (ILO) recognized the situation of indigenous people and defended their rights in 169 convention which promoted the UN Declaration on the Rights of Indigenous Peoples (UNDRIP) to pursue greater action in General Assembly, 2007 in Article 41.

UN Permanent Forum on Indigenous Issues (UNPFII), a fellow UN agencies developed a framework for the needs, issues, religion and cultural values, self -identification, recognition, dispossession, exclusion or discrimination respectively on the principles of [1] Self-determination, [2] Development with identity, [3] Free, prior and informed consent, [4] Participation and inclusion, [5] Rights over land and other natural resources, [6] Cultural rights [7] Collective rights, [8] Gender equality for the development of indigenous people of the world as a whole. In framing the policies it emphasized the following priority areas such as, [1] Natural resources, environment and genetic resources, [2] Climate change and bioenergy, [3] Land and territories, [4] Food security, nutrition and the right to food, [5] Communication and knowledge systems, [6] Cultural and biological diversity, [7] Economic opportunity for sustainable livelihoods respectively. It has considered some policy mechanism such as [1] Information sharing and analysis which consists of [i] Awareness-raising, [ii] Communication and data collection,[iii] Research with indigenous communities, [2] Policy dialogue and normative work, that entails [i] Dialogue, [ii] Participation/inclusion, [iii] Standard-setting, [3] Field programme, which comprised of [i] Capacity development for indigenous peoples, [ii] Capacity development for FAO staff, and [4] Resource mobilization and 
increased coordination that constitutes [i] Collaboration in resource mobilization, [ii] Coordination and cooperation within the UN system, [iii] Collaboration within FAO respectively.(ILO,2020).

\subsubsection{Recognition of international institutions on legal provision for indigenous people:}

[1] In 1957, ILO under convention 107, codified indigenous people to have conditions of improved living and working under the obligation of the state. Later, in 1989, under convention of 169, it provided the rights of indigenous people. [2] In 1992, under Agenda-21 of the Rio Declaration, indigenous people was recognized as a major group to be a part of sustainable development. [3] In 1993,UN Conference on Environment and Development in Article 8(i) and 10 (c) on Biological Diversity admitted the significant contribution of indigenous peoples to environmental conservation. [4] In 1994,in Article 16(g) and 17(c), UN Convention to Combat Desertification calls for the protection of indigenous traditional knowledge, technologies and practices. [5] UN Declaration of the Rights of Indigenous Peoples-2007 established rights of violation against them and protected their livelihood and Anchorage Declaration-2009 called FAO to address the impacts of climate change on food security and food sovereignty. [6] In 2009, UN-REDD Programme ensured the participation of local indigenous peoples. [7] In 2007, Global Plan of Action for Animal Genetic Resources calls on to support indigenous and local production systems and associated knowledge systems of importance to keep up proper maintenance and sustainable use of animal genetic resources.

\subsubsection{Policy recommendations for India in relation with international institutions}

India ratified ILO convention no-107 on the Protection and Integration of Indigenous and Other Tribal and SemiTribal Populations in Independent Countries but in 169.7 convention asserted that it is not yet finalized. India should consistently and effectively implement the Fifth and Sixth Schedules of the Constitution and the PESA Act, including extension of model of autonomous councils and local bodies. On the recommendations of CERD, India should implement the Scheduled Caste and the Scheduled Tribes Act, including special courts and other measures. As per CEDAW's recommendation, India should implement strong special measures for women and girls from scheduled tribes to enroll in education and employment and to be aware rising campaigns sensitizing security and media agencies to enhance multiculturalism and tolerance. India should enact the recommendation of National and State Human Rights Commission who repeal the FCRA which has been increasingly used to obstruct civil society's access to foreign funding. It fails to comply with the norms and standards of international human rights as called on by UN Special Rapporteurs. India should implement forest rights act which can promote the community forest rights claims by tribal communities adequately. India should also reconstitute the CAMPA law vis-à-vis the Forest Rights Act so as to guarantee the status of tribal and forest dwelling communities during the process of reformed and redefined conservation projects. It must implement LARR Act of forest right act before undertaking any infrastructure development and mining plans and projects in tribal areas. India should formulate a National Action Plan for implementation of the UN Guiding Principles on Business and Human Rights of tribes. Government should protect them by law in collaboration with UN. The Government should stop militarization in tribal areas without the free, prior and informed consent of the concerned tribes.

\subsection{United Nations Framework Convention on Climate Change (UNFCCC)}

In 1997, indigenous people emerged in the UN system to represent them. Most of the government believed that the role of indigenous and local community in-depth knowledge of the environment. Government can help scale up and accelerate the global effort to mitigate and adapt to climate change in a holistic process. Indigenous peoples and local communities take full responsibilities at the front lines of climate change and they also hold many of the solutions to adapting to climate change. The executive Secretary of the UNFCCC said that the indigenous people must be part of the solution to climate change because they have the traditional knowledge of their ancestors. The important value of that knowledge simply cannot and must not be understated. They are also essential in finding solutions today and in the future. The Paris Climate Change Agreement recognizes it. It recognizes their role in building a world that is resilient in the face of climate impacts. In addressing climate change under Decision 1/CP.21, the UNFCCC claimed that the rights of indigenous peoples and local communities should be respected, promoted and considered. The COP Presidency affirmed that governments, indigenous peoples and local community would work together in pursuit of a sustainable and climate-resilient 
world that leaves no one behind. The COP has recognized the need to strengthen knowledge, technologies, practices and efforts of local communities and indigenous peoples related to addressing and responding to climate change (UNFCCC,2018).

The following are the outcomes of COP21 from Lima,2014 in consultation among the representatives of indigenous groups with UNFCCC, IIPFCC and UNPFII respectively.

[i] Indigenous peoples and local communities are supported in preparing to engage effectively in COP 21, [ii] they are meaningfully and visibly represented at COP 21, [iii] The key outcomes of COP 21 are communicated to indigenous peoples and local communities around the world and follow up dialogue is supported, [iv] Major commitments and announcements of relevance to the indigenous and local agendas are mobilized, and highlighted at COP 21, [v] The impact of climate change on indigenous peoples and local communities, and their role in contributing to climate solutions is communicated to governments and the global public(UNDP, 2015 May 25).

Ford et al. (2016) studied the sensitivity of the indigenous peoples' activities under UNFCCC since COP16 in Cancun,2010 where more adaptation, value added in traditional knowledge, forest protection under climate change were given priority and found that the indigenous people achieved greater opportunities in living and engagements in post-Paris agreement.

After COP26, UNDP itself recommended the following agenda for the upliftment of indigenous people in the world.

[a] Provide a platform to indigenous peoples and involve them in relevant policy processes, [b] Include and promote indigenous peoples' knowledge and practices in climate policies, [c] Respect, protect and promote the rights of indigenous peoples.

\subsection{World Bank (IBRD)}

In 1980-82, a bank staff elaborated the first World Bank policy on tribal peoples without any participation by indigenous peoples. Real engagement between the Bank and indigenous peoples on policy and accountability issues first occurred in 1987 under the presidentship of Barber Conable who finally admitted that many of World Bank projects had resulted in negative impacts on indigenous peoples and their environment (Griffiths,2005)

The World Bank issued Operational Manual Statement, OMS 2.34 in 1982 February as the first policy directive under the title "Tribal People in Bank financed Projects". During 1982-1986,33 bank financed projects were identified, appraised and implemented 15 projects in which 11 were from Latin America and the Caribbean region, 2 from Africa, and 2 from Asia and the Pacific region. In 1984, the total number of projects was 36 which had increased to 53 in 1986.

In 1991, the World Bank extended the definition of indigenous people (in OD 4.20) to a much wider array of people who maintain social and cultural identities distinct from those of the national societies where they live and are attached closely to their ancestral land.

The projects of OD 4.20 contain IPDP and are based on the active participation of the affected tribal or indigenous populations which include a special plan for the incorporation of tribal peoples in a rubber cultivation project in India. It is an agricultural and rangelands management project with Bedouin tribes in the western desert of Egypt. It is a natural resource management and forestry project with indigenous and Afro-American communities in the Choco region of Colombia. The Bank played a pivotal role to promote the participation of indigenous peoples in the implementation of the recommendations of the reports and conferences (The report of the World Commission on Environment and Development, the World Conservation Strategy, and the Agenda 21 document of the United Nations Conference on Environment and Development), because of its central role in such institutions as the Global Environmental Facility (GEF) and it's more than a decade of experience attempting to promote among its Borrowers the rights of tribal and indigenous peoples (Davis, 1993).

It was found from a review of the World Bank under OD 4.20 that indigenous people were involved in decision making and participation in 38\% of the project during 1992-2001.Again,the review in 2004 stated that 48 full- 
size and medium-sized projects undertaken by the World Bank found that just $28 \%$ of its biodiversity projects in Latin America involved high levels of indigenous participation on project design. The same review found that $38 \%$ of projects suffered from "low" participation of indigenous peoples and only limited involvement of indigenous peoples in project preparation (Griffiths, 2005). Author finds that the World Bank policy on participation of indigenous people in the projects was not favourable to them to address demands that indigenous peoples have made for the last 15 years e.g., in relation to human rights and free, prior and informed consent (FPIC). Although recent independent sector reviews sponsored by the Bank have enabled more effective participation, but the Bank had not succeeded to implement their progressive recommendations producing disillusion among indigenous peoples who were engaged in these processes.

The recognition of tribal people in the economic development process in course of their surveillance had been first granted by the World Bank as an international development agency. The same source wrote that the World Bank's proposed policy, if fully implemented, would support their rights to their lands, resources, ethnic identities and cultural autonomy.

The World Bank Board of Directors sanctioned US\$80 million project in March 2018 to improve infrastructure and quality of health, education, water and sanitation services in 12 indigenous territories of Panama under national plan in which Maria Luisa Romero-the Minister of Panama said that from the outset, the government has been firmly committed to defending and promoting human rights in which increased participation of indigenous people and state policies to improve their quality of life are central issue. Moreover, Seynabou Sakho-the World Bank Director of Central America said that the project is an important step towards improving the social mobility of indigenous peoples and reflects the World Bank's commit to supporting the most vulnerable population. This proves that indigenous people are inclusive, development and access to information for coordination between the government and indigenous leaders. (Press release, World Bank, 15/3/2018).

\subsection{The African Development Bank (AfDB)}

The African Development Bank (AfDB) is the only multilateral development bank which explicitly recognize the rights of indigenous peoples in concrete form which is considered as a positive step of AfDB and reflects a growing acceptance of indigenous peoples' rights on the continent under new environmental and social safeguards. The CSO Coalition between the AfDB and Indigenous Peoples of Africa Coordinating Committee (IPACC) have jointly advanced and elevated the issue of indigenous peoples at AfDB, preparing a joint paper calling for a standalone safeguard policy on indigenous peoples and requested to start formal dialogue between indigenous peoples and the Bank.

AfDB President Donald Kaberuka agreed to host a forum on indigenous peoples in February 2013, which served as a useful exchange to begin dispelling misconceptions within the Bank about the existence of indigenous peoples in Africa. Finally, it was decided that the indigenous peoples are directed to grant or withhold their free, prior and informed consent for projects impacting on their rights. Ultimately, the Bank staff provided a liaison point for indigenous peoples and tasked with advancing the application of new standards to convene an advisory board of indigenous peoples, and to devote sufficient attention and resources for training. The Bank risks approving standards which cannot be approved without such attempts (Forest People Programme, 2013).

African Development Bank Group (2016) developed an overview of the state of indigenous people in Africa highlighting the options for their inclusion. It aims to understand the needs of the indigenous people to promote their welfare and ensure the benefit of growth. Bank believes in providing their rights, property, culture, using natural resources giving importance to IPACC recommendations. The Bank will consider a social investment programme as a vehicle target including socioeconomic development. Bank also desires to protect them from violent conflicts, climate change, land dispossession, uneven distribution of resources and exclusion, marginalization and exploitation.

The African Development Bank has been experiencing the following projects with the inclusion of indigenous people so far, [i] The Private Sector Kriti Power Project, [ii] The Lom Pangar Hydro-power Project, [iii] 
Mombasa-Addis Ababa Road Construction and Upgrading 2012, [iv] The Koka Hydro-Electric Dam Expansion, [v] Gilgel Gibe III Dam in Ethiopia, [vi] Nuweiba Power Plant and nomadic Bedouin in Egypt and so on.

\section{International Organizations and Indigenous people}

\subsection{International Alliance of Indigenous and Tribal Peoples of the Tropical Forests (IAITPTF)}

The International Alliance of Indigenous and Tribal Peoples of the Tropical Forests (IAITPTF) set up in 1992 in Malaysia during indigenous conference for fighting rights and living in tropical forest regions in Africa, Asia Pacific and America. An International Coordinating Committee (ICC) of the alliance decided to meet at least twice a year to monitor the work of the Alliance. They constituted the Regional Coordinators which was supported by a regional secretariat and the International Technical Secretariat. Every Regional Coordinator is a representative of one of the nine regions falling within the Alliance's remit. The names of the regions are :Central America( which consists of Panama, Costa Rica, Nicaragua, Honduras, El Salvador, Belize, Guatemala and Mexico), South America (Its members are Ecuador Paraguay, Argentina, Brazil, Peru, French Guyana, Bolivia, Guyana, Surinam, Venezuela and Colombia),Central Africa( whose members are Democratic Republic of Congo, Rwanda, Congo Brazzaville, Burundi, Central African Republic, Gabon and Cameroon ),West Africa( in which Nigeria, Togo, Benin Republic, Niger, Gambia, Senegal, Liberia and Sierra Leone are members),East Africa(which consists of Kenya, Uganda, Tanzania and Southern Sudan),South Asia( which consists of Sri Lanka, India, Nepal, Bangladesh and Bhutan),South-East Asia( where Thailand, Burma, Lao PDR, Cambodia and Vietnam are members ), Bahasa ( which consists of Malaysia, Indonesia and the Philippines) and Pacific( whose members are Fiji, Solomon Islands, Papua New Guinea, Vanuatu and New Caledonia).

It is working with [i] Convention on Biological Diversity (CBD), Article (8(j),[ii] Follow-up on the Action Plan of the World Summit on Sustainable Development (WSSD) and the World Conference Against Racism (WCAR),[iii] UN Forum on Forests (UNFF),[iv] UN Framework Convention on Climate Change (SBSTA, COP),[v] UN Working Group on Draft Declaration, [vi]UN Working Group on Indigenous Populations (WGIP),[vii] Permanent Forum on Indigenous Issues (UNPF),[viii] World Bank (and other multilateral organizations) policy on Indigenous Peoples,[ix] World Parks Congress and [x]World Intellectual Property Organization (WIPO)respectively.

The variety of objectives of the IAITPTF are [i] to promote full recognition of the rights and territories of indigenous and tribal peoples, [ii] to advance the development of indigenous peoples and their participation in decision and policy making, [iii] to establish effective networks between indigenous peoples at regional and international levels, [iv] to interchange information and experiences to empower alliance members to provide for the rights of indigenous peoples to coordinate with international institutions, [v] to promote worldwide solidarity between indigenous and tribal peoples(Forest People Programme,2020).

\subsection{Global Forest Coalition (GFC)}

Global Forest Coalition (GFC) set up in 2019 March in Lomé, Togo. GFC has 99 indigenous and non-indigenous member groups from 65 countries as on 31 December 2019. It supports the struggles of Indigenous People and local communities by bringing their views, positions and proposals to the forefront of local, national, and global forest-related decision-making processes. It has been advocating for the conservation and restoration of forest ecosystems through the promotion of the rights, territories, traditional knowledge and sustainable livelihoods of the Indigenous Peoples.

GFC have developed a detailed internal control system, and organized annual monitoring, evaluation and planning meetings for GFC's Advisory Council. It has huge visions to [i] Protect real forests, and the people dependent on them, [ii] Protect the rights of forest peoples, [iii] Halt deforestation and biodiversity loss, [iv]Protect Biodiversity through cultural diversity. Its objectives to increase public and political awareness, to ensure the rights of indigenous peoples, to protect and promote customary systems of forest governance and conservation, and the traditional knowledge of indigenous peoples, to ensure community's conservation and restoration initiatives, to facilitate and support regional and international alliances of organizations and communities working to defend forests and forest peoples. The function of GFC is the alternate co-facilitator of the Women's Major Group 
(WMG) at the United Nations Environment Assembly (UNEA-4). It has obtained a huge success in the adoption of the Women and Environment resolution at the UNEA-4 (Global Forest Resource Coalition,2020).

The GFC Report-2019 stated that GFC's Women 2030 partners carried out in-depth gender assessments on the implementation of key Sustainable Development Goals (SDGs) in eight countries on women's rights, community conservation and climate campaigns. In March 2019 in Lomé, Togo, 32 representatives of local community groups, women's rights groups and NGOs came together to participate in a West African skill share on gendersensitive, community-based forest conservation and restoration, and a strategy meeting on bioenergy generation. The member group les Amis de la Terre-Togo hosted the skill-share. The press statement was issued by the participants asserting respect for traditional knowledge and the importance of community-led conservation. During 2019, GFC's Women 2030 partners trained on 570 community-based organisations in 14 countries (India, Nepal, Sri Lanka, Kenya, DRC, Tanzania, Ghana, Kyrgyzstan, Georgia, Colombia, Paraguay, Chile, Bolivia and Brazil) on women right to community conservation and food sovereignty. A successful strategy of the Women 2030 program in 2019 was to create a few women to become leaders and role models in their communities who worked together to empower other women in their communities and further afield to accelerate women's empowerment and gender equality to move communities closer towards gender equality. Their campaign on forests, trees and climate change of forest loss and land conversion to monoculture tree plantations induced people about afforestation/ reforestation and carbon markets, climate finance directed towards commercial tree plantations and a number of cross-cutting issues such as gender justice and the rights of indigenous peoples. The report emphasized that GFC co-organised an African Regional Dialogue on Unsustainable Livestock in Addis Ababa, Ethiopia in 2019 September with 90 participants representing a diverse range of pastoralist communities, indigenous peoples, women's rights groups, environmental activists, animal welfare organizations and UN agencies. The report appreciated that despite the reality of ever-worsening climate, biodiversity and social crises, including the COVID19 pandemic that hit the world in early 2020, the vital work GFC members were to clear path towards forest protection, planetary and human health and respect for the rights, knowledge and practices of forest peoples(GFC Annual Report, 2019).

\subsection{International Work Group for Indigenous Affairs (IWGIA)}

The International Work Group for Indigenous Affairs (IWGIA) was established in 1968 in Denmark during 38th International Congress of Americanists, held in Munich and Stuttgart and funded by the Nordic Ministries of Foreign Affairs and the European Union. It is an independent and non-profit international human rightsbased membership organization to promote the collective rights of the world's indigenous peoples. It is functioning with United Nations Economic and Social Council (ECOSOC) and has observer status with the Arctic Council and with the African Commission on Human and Peoples' Rights. It was initially treated posed by the rapid development of settlements and industries to the indigenous groups living in the Amazon Basin. It supported regional and thematic programme of indigenous people in Asia, Africa and Latin America and Russia on climate change, indigenous participation in climate change process and REDD+ strategies including human rights and publication programme.

The annual report of IWGIA in 2019 claimed that IWGIA supported indigenous peoples in the Amazon who are defending forested lands from the catastrophic fires throughout 2019 where it is concerned with burning of $130,000 \mathrm{~km}^{2}$ of land and forests in Siberia which were detrimental to the lives and livelihood of the indigenous peoples who depend on the forest by protecting it. The report defended the indigenous peoples' environment and rights since 500 indigenous people have been killed since 2017.

IWGIA does not support marginalization of indigenous peoples, racism and disrespect or outright criminalization of their traditional use of natural resources and livelihoods, adds to their vulnerability but supports selforganization and mobilization projects in many countries. IWGIA supports the global indigenous movement on current climate change context, by facilitating indigenous peoples' participation at various high-level international UN agencies and human rights mechanisms. IWGIA also facilitates international meetings on variety of key issues, including territorial governance. The leaders of IWGIA know indigenous peoples' issues during 25 years of research with forest communities on the linkages between climate change, indigenous peoples' rights and 
tropical forest conservation. IWGIA will focus on institutional and fundraising issues in 2020. It will develop a new Institutional Strategy for the organization incorporating four new programmes such as Land Defense and Defenders, Territorial Governance, Climate Change and Cross-Cutting Global Governance as well as the implementation of a small grant facility respectively.

In 2019 at Baku during the $43^{\text {rd }}$ session of World Heritage Committee adopted resolution on the recognition of indigenous peoples' right in the heritage sites because out of 1121 heritage sites of UNESCO, roughly $10 \%$ incorporated indigenous lands, territories and resources in which violation against them had occurred and repeatedly excluded from the process and even from monitoring and management.

Up till 2019, IWGIA published 7 books,50 news articles and 1 urgent alert and produced hundreds of podcasts, documentaries, news programmes and other materials in local languages. The website of it was visited over 490000 times in 2019 reaching 7300 subscribers with 26000 followers.

IWGIA has been representing in the Council of the International Land Coalition (ILC) during the three years among 250 organizations on people-centred land governance to secure territorial rights for Indigenous Peoples. It is taking an active part in the development of a new ILC strategy in 2020 with other 50 international, regional and national organizations (including ILC). IWGIA also joined the Defending Land and Environmental Defenders Coalition in 2019 and has been an active member. In 2019 November in Geneva, UN Forum on Business and Human Rights organized a programme on Zero Tolerance Initiative led by indigenous people with the support from Forest Peoples Programme (FPP), the Business and Human Rights Resource Center, Asia Indigenous Peoples Pact (AIPP) and IWGIA. This programme attempted to find effective ways to hold companies and investors to account for killings, criminalization and human rights abuses happening against (Environmental) Human Rights Defenders in their supply chains.

In 2019, IWGIA also signed institutional agreements with 2 universities in Latin America. IWGIA is now developing a diploma programme on indigenous people's rights for the second semester of 2020 with NUR University of Santa Cruz de la Sierra, Bolivia. Additionally, the Faculty of Law of Santiago University in Chile is providing legal advice to IWGIA and its indigenous partners in the prior consultation processes in Latin America (IWGIA Annual Report, 2019).

\subsection{Indigenous Peoples Law and Policy Program (IPLP)}

The Indigenous Peoples Law and Policy (IPLP) Program usually conducts research, training and advocacy of Indian law and international law of indigenous people with the James E. Rogers College of Law at the University of Arizona. This programme is continuing with the people of Awas Tingni, a Mayangna (Sumo) indigenous community located on the Atlantic Coast in Nicaragua and assisted Central American Maya villages that have filed lawsuits in the Belize Supreme Court alleging that both the attorney general of Belize and the minister of Natural Resources and Environment had violated their property rights. ( https://law.arizona.edu/indigenouspeoples-law-policy).

It had introduced a Spring Mini-Course on The Law, Policy, and Economics of Contemporary Tribal Economic Development. The Rogers College of Law in University of Arizona adopted an interdisciplinary Master of Laws (LLM) Program in Indigenous Peoples Law and Policy to offer candidates. This course is an intellectually exciting and professionally rewarding graduate legal educational experience in the field of Indigenous Peoples Law and Policy. It also conducted a course on Master of Law Programs in International Trade and Indigenous Peoples Law and Policy which can fulfill the overall mission of the Indigenous Peoples Law and Policy Program. (https://web.archive.org/web/20081011230526/http://www.law.arizona.edu/depts/iplp/about.cfm?page=about)

\subsection{The Center for World Indigenous Studies (CWIS)}

The Center for World Indigenous Studies (CWIS) is known as a nonprofit American organization. It was set up in 1979 as a research and documentation clearing house but it was incorporated in 1984 by Rudolph C. Ryser, Ph.D. (who was brought up as a member of the Cowlitz tribe). Usually, the Evergreen State College has a good reputation of educational service to the tribes. With the help of the development of the Northwest Indian Applied 
Research Institute, the college is committed fully to the indigenous people of Western Washington to offer the services to the tribes enabling assistance to local tribes to meet their economic, governance and resource goals. (https://web.archive.org/web/20081012032136/http://nwindian.evergreen.edu/research-guidelines.html)

\subsection{Indigenous Peoples Council on Bio-colonialism (IPCB)}

The Indigenous Peoples Council on Bio-colonialism (IPCB) set up in 1999 which is a non-profit organization for the purpose of political activism against the emergent field of population genetics for human migration research .It does not support traditional Native American accounts and narratives about their ancestral origins, and carried alternative views.

IPCB initiated genetic variation research on isolated populations with its prospective commercial exploration. It believed that it is a global threat to the self-determination of all indigenous peoples and to the non-indigenous world and to the earth itself. It encourages indigenous people to protect their genetic resources, knowledge, culture, human right and negative effects of biotechnology. (https://en.wikipedia.org/wiki/Indigenous Peoples Council on Biocolonialism).

Indigenous Peoples Council on Bio-colonialism (2006) expressed that the ABS refers to access to genetic resources and benefit sharing in which genetic resources refers to the genes that make up every living organism, which are seen as resources that can be bought and sold and access referred to traditional knowledge for the purpose of research and development of a pharmaceutical, chemical, agricultural or other products towards the path of commercialization. In 2002, Paris convention adopted Bonn guidelines on ABS and World Summit on Sustainable Development in 2002, and COP7 in 2004 elaborated five possible elements related to indigenous peoples (VII/19D annex) which limited to traditional knowledge which includes,[i] Article 8(j) on holding traditional knowledge associated with genetic resources,[ii] keep up origin of genetic resource of traditional knowledge,[iii] provide recognition and protection of the rights of indigenous and local communities over their traditional knowledge which are associated with genetic resources with respect to the national legislation of the countries where these communities are located,[iv] Customary law and traditional cultural practices of indigenous people [v] to ensure Code of ethics/code of conduct/models to ensure fair and equitable sharing of benefits with indigenous communities. The World Intellectual Property Organization (WIPO) and CBD proposed 'positive' or 'defensive' protection of traditional knowledge. IIFB stated that traditional knowledge is dynamic, not static and cannot simply be documented and fixed in a tangible form to suit intellectual property law standards (Convention of Biological Diversity, 2020).

Harry and Kanehe (2006) studied that how to establish strong protections over their genetic material and indigenous knowledge, why genetic material should be protected as cultural property, why tribes need to be concerned about research involving genetic material and indigenous knowledge, with a particular focus on human genetic research, to examine the extent of the protection that they assert over genetic material and Indigenous knowledge, as well as their regulation of research. It hoped that tribes would inevitably be faced with making decisions about the patenting of life forms and commodification of genetic material and indigenous knowledge. Author believed that indigenous peoples' heritage should be documented on film, photographs, videotape, or audiotape. Above all, indigenous peoples' cultural property can be conceived as a bundle of relationships rather than a bundle of economic rights.

Indigenous peoples have challenged patents on their genetic material and have struggled to repatriate samples from institutional gene collections.

A tribal code for the protection and management of archaeological, historical, and cultural resources was approved by the Confederated Tribes of Warm Springs of Oregon. At the outset of the protection and management of archaeological, historical and Cultural Resources Code, the tribe sets out tribal policy and intent to manage ancient and contemporary cultural use of sites and materials including traditional foods and other natural resources.

A non-exhaustive list of cultural materials such as eagle feathers, fish, game, roots, berries, cedar bark, Indian medicines and water were designated significantly by the tribe as a part of the code. The Code prohibits removal of protected objects from tribal lands without a permit misused by the tribal council. Without the permission from 
the tribal council no sale, purchase, exchange, transport, receipt or offer to sell, purchase or exchange of any product can be executed.

In September 2000, the Indigenous Peoples Council on Bio-colonialism (IPCB) announced the release of the Indigenous Research Protection Act (IRPA) which is a model ordinance developed by the IPCB to help American Indian tribes to protect their peoples and resources from unauthorized research so as to reduce the adverse effects of research on the tribal community. It will ensure that researchers may recognize tribal control and ownership of all information which is generated or produced by the research and finally it will establish a statutory basis for the governance of research within their jurisdictions.

Tribes can establish regulatory frameworks, such as IRPA, for research and the protection of cultural property as an assertion of sovereignty under a legal framework. Indigenous peoples who are creative and assertive in their regulatory schemes will be protected through multiple levels in their biological and cultural property in a manner consistent with their own cultural values, traditions, and customs.

\subsection{International Indian Treaty Council (IITC)}

The organization of International Indian Treaty Council (IITC) was established in 1974 consisting of indigenous people from North, Central, South America, the Caribbean and the Pacific who have been protecting Indigenous Rights, Treaties, Traditional Cultures and Sacred Lands. Since 1977, the IITC has been recognized by the United Nations as a category II Non-governmental Organization (NGO) with Consultative Status with the UN Economic and Social Council, making it the first indigenous NGO to gain such status. The IITC aims to build, organize and facilitate the participation of indigenous peoples in local, regional, national and international events and gatherings addressing their concerns and survival. It is working in cooperation with Commission on Human Rights, the Working Group on Indigenous Populations, the Sub-Commission on Prevention of Discrimination and Protection of Minorities, the Conference of the Parties to the Convention on Biological Diversity, UNESCO and the Commission on Sustainable Development. Of late, IITC has also participated in the International Labour Organization, U.N. World Conferences, the International Union for the Conservation of Nature and the World Archeological Congress. The objectives of IITC seek to promote and build participation of indigenous peoples in the United Nations (UN).Its specialized agencies seeks to internationalize recognition for Treaties and Agreements to support the human rights, self-determination and sovereignty of Indigenous Peoples, to build solidarity and relationships of mutual support and to disseminate information about their human rights issues. In April 2002, in Sololá, Guatemala, IITC organized the first Indigenous Peoples' Global Consultation on the Right to Food. (https://en.wikipedia.org/wiki/International_Indian Treaty Council).

\subsection{International Indigenous Peoples Forum on Climate Change (IIPFCC)}

The International Indigenous Peoples Forum on Climate Change (IIPFCC) representing the seven regions of the IIPFCC-Africa, the Arctic, Asia, Latin America \& the Caribbean, North America, the Pacific, and Russia \& Eastern Europe, set up in 2008 to participated in the UNFCCC processes to interact with SBSTA/SBI bodies in COPs IP agreements. It participated UNFCCC 21st Conference of the Parties (COP 21) at Le Bourget, Paris to serve hundreds of indigenous peoples from around the world to communicate key messages, to facilitate knowledge exchange, and to share innovative solutions to climate change. It hosted over 80 events, representing almost 300 distinct indigenous groups, networks and supporting organizations arranging debates, panel presentations and discussions, press conferences, film screenings, workshops and cultural performances which facilitated the exchange of knowledge and experiences among indigenous peoples. It is funded by the Government of Norway and the COP Presidency of France. ( http://www.iipfcc.org/.)

\subsection{Tribal Cooperative Marketing Development Federation of India (TRIFED)}

The Tribal Cooperative Marketing Development Federation of India (TRIFED) was established in 1987.It is a national-level apex organization under the Ministry of Tribal Affairs, Govt. of India consisting of 13 regional offices. Its aim is socio-economic development of tribal people and marketing development of tribal products such as metal craft, tribal textiles, pottery, tribal paintings and pottery. It tried to empower tribal people with knowledge, tools and pool of information. It also functions as a facilitator and service provider for tribes and 
creates capacity building of the tribal people through sensitization, setting up of Self-Help Groups (SHGs) and conducting training to them. It provides information related to fair price markets for the Minor Forest Produce, helps in increasing the bargaining power of the tribes to fetch good prices for the MFP. (https://www.legacy.com).

\subsection{The Indigenous Peoples of Africa Co-ordinating Committee (IPACC)}

The Indigenous Peoples of Africa Co-ordinating Committee (IPACC) was founded in 1997 by indigenous peoples' organizations from Africa, and it is accredited with the United Nations Economic and Social Council (ECOSOC). IPACC is active in all three of the United Nations Multilateral Environmental Agreements developed in Rio in 1992 - including the UN Framework Convention on Climate Change (UNFCCC). The Indigenous Peoples of Africa Co-ordinating Committee (IPACC) consists of 135 indigenous peoples' organizations in 20 African countries. It is a membership organization. Members elect an Executive Committee representing six geographic and cultural regions in Africa including a special regional representative of indigenous women. It is fighting against human rights violations, systematic legal and social discrimination, and exclusion from decisionmaking and the political economy. It is studying to understand and engage with international human rights mechanisms and special procedures, in order to secure the human rights of indigenous peoples, to engage with indigenous communities, governments, regional bodies and the United Nations for the protection of the fundamental human rights of indigenous peoples, and to promote gender equality in indigenous organizations and communities. Generally, IPACC promotes and supports on climate justice for indigenous communities, land rights of indigenous communities, the intellectual property rights which are contained in the Indigenous Knowledge Systems of Africa's First Peoples (https://www.ipacc.org.za/about/).

The introduction to indigenous traditional knowledge in adaptation is a response to UNFCCC policies and guidelines, including the Cancun Adaptation Framework, the National Adaptation Programmes of Action (NAPA), the National Adaptation Plans (NAP), as well as other policy instruments, UN norms and standards on indigenous and traditional knowledge.

Crawhall, et al. (2016) studied IPACC's own experience of indigenous traditional knowledge (ITK) in rural areas in which ITK is responding to UNFCCC policies and guidelines, including the Cancun Adaptation Framework, the National Adaptation programme of Action (NAPA), the National Adaptation Plans (NAP) and authors suggested some tools to complement [i] Monitoring and responding to changes in plant and wildlife density and diversity due to climate impacts, [ii] Developing longitudinal and accurate studies of plant, wildlife and human behaviour changes, [iii] Human, wildlife and livestock disease monitoring and management, [iv] Anti-poaching programs, [v] Traditional and inter-community water management, [vi] Customary resource regimes (who has the right / duty in which geographic area under what rules and circumstances), [vii] The role and function of traditional institutions in conflict avoidance associated with de-stabilized natural resource governance regimes.

\section{Limitation and future scope}

There are many other international legal and financial institutions that work for indigenous people which are not included here for analysis. Even many international organizations which maintain the rights and livelihood of the indigenous people are excluded from here. In future research their activities, aims, objectives, performances might be analyzed for new scopes.

\section{Conclusion and remarks}

The activities of the above described indigenous organizations and other international institutions who are working for the interest of them are not enough to be explained. There are many institutions in the world which have been serving the tribes. Coates (ed.). (2004) argued that the future of indigenous people is uncertain and their aboriginal response is complex although the history of governance expressed and utilized their monstrous and their occupation status and the Christian missionaries and charities through their aids, education, medical services, dwelling, livelihood objectives challenged the institutional structures of the societies and their survival. How they will coexist with non-violence, rebalance with neo-spiritualism and keep away from stratification is a millionaire question. 
Lack of institutional co-ordinations, failure of inclusive policy, process of globalization and liberalization, bureaucracy of government has been hindering the survival of indigenous people constantly which have triggered tribal unity on a large scale nationally and internationally. Survival International is such type of institution which was set up in 1969 and have won Right Livelihood Award, Premio Leon Felipe Award of Spain and Medaglite della Presidenza della Camera Lei Deputati award of Italy, have been working on education, advocacy and campaign for rights of indigenous people. It has been publishing materials to spread in developed and underdeveloped countries, spreading their voices through sponsorship, leaflets, demonstrations, film shows, collecting money, printing documents and facts and using media. Their organization supports 150 tribal people with 100 uncontacted people in 60 countries having supporters of 60 nations. They have been fighting on the right of ownership, law, and the freedom campaign against invasion of their lands for exploration resources which forced them relocation, loss of sustainability and way of living. Even, they are treated as with racist disdain by neighbours, forced them into violence, alcoholism and sexual abuse (Survival International,2017).

Bhowmik (2018) critically explained the debating issues of the nature of rights, duties and responsibilities of indigenous people on forests in order to protect its environment and ecosystem because it is fact that in the name conservation, the tribes have been evicted by multinationals in collaboration with government so that their survival problem is now at stake for which world-wide protests began to raise the voices of the indigenous people which was seen in the last World Summit.

On behalf of Asian Indigenous Women's Network, Cordillera Peoples Alliance Philippines, Indigenous Environmental Network, Indigenous Initiative for Peace, Indigenous Women's Network, International Indian Treaty Council, Na Koa Ikaika Kalahui Hawaii, and Tebtebba Foundation, the indigenous people assembled and demonstrated in the 5th WTO Ministerial Conference in Cancun, Mexico from 10-14 September 2003.They claimed that after implementing structural adjustment policies of the World Bank and International Monetary Fund with the creation of WTO, the situation of indigenous peoples has turned from bad to worse and their knowledge, cultures and identities are grossly violated.

They stated that [i] the livelihoods of hundreds of thousands of indigenous peasants in Mexico have been damaged, [ii] increased impoverishment of indigenous and hilltribe farmers engaged in coffee production in Guatemala, Mexico, Colombia, Vietnam, etc. because of fell down of price of coffee, [iii] conflicts were increasing between transnational mining, gas and oil corporations and indigenous peoples in the Philippines, Indonesia, Papua New Guinea, India, Ecuador, Guyana, Venezuela, Colombia, Nigeria, Chad-Cameroon, USA, Russia, Venezuela, among others and the militarization and environmental devastation in these groups, [iv] started the militarization of indigenous peoples' lands and territories, [v] they are homeless due to mega hydroelectric dams, oil and gas pipelines, roads in indigenous peoples territories, logging corporations, and export processing zones,[vi] loss of livelihood due to patenting of medicinal plants and seeds nurtured and used by indigenous peoples,[vii] Privatization of basic public services such as water and energy.

Naturally they raised the demand to WTO in the following heads, [i] Recognize and protect our territorial and resource rights, [ii] Stop patenting of life forms and other intellectual property rights over biological resources and indigenous knowledge, [iii] Ensure indigenous peoples' basic right to health, [iv] No new issues should be negotiated in this 5th Ministerial Conference, [v] Prevent the expansion of the GATS Agreement, [vi] Stop the negotiations on agriculture, [vii] End the militarization of Indigenous Peoples' communities, [viii] Support and strengthen the sustainable trading systems.

(https://www.ienearth.org/the-international-cancun-declaration-of-indigenous-peoples/)

Funding: self-funded.

Author contribution: conceptualization: Debesh Bhowmik; data curation: Debesh Bhowmik; formal analysis: Debesh Bhowmik; funding acquisition: Debesh Bhowmik; investigation: Debesh Bhowmik; methodology: Debesh Bhowmik; project administration: Debesh Bhowmik; resources: Debesh Bhowmik; software: Debesh Bhowmik; supervision: Debesh Bhowmik; validation: Debesh Bhowmik; visualization: Debesh Bhowmik; writing - original draft: Debesh Bhowmik; writing - review \& editing: Debesh Bhowmik. 
1. African Development Bank Group (2016). Development and Indigenous People in Africa. Available at: [Google Scholar], [Link].

2. Babar, Aniruddha Vithal (2016). Analytical Study of the Impact of Globalisation on tribal communities in India with reference to Economic Justice, All Inclusive Growth and Social Transformation. Journal of Poverty, Investment and Development, 21, 31-39. Available at: [Google Scholar], [Link].

3. Bhowmik, Debesh (2017). In search of the tribes around the world. In Bhowmik, Debesh \& Das, Sourav Kumar (Eds.), Issues on Tribal Development (pp 1-43). Kolkata: Rupali. Available at: [Link].

4. Bhowmik, Debesh (2018). Survival of Indigenous People: Environment Protection and Conservation. In Bhowmik Debesh (Ed.), Developmental Issues of Tribes(pp143-160). New Delhi: Shandilya Publications. Available at: [Link].

5. Coates, Kens (Ed.).(2004).A Global History of Indigenous Peoples: Struggle and Survival. New York: Palgrave Macmillan. Available at: [Link].

6. Convention of Biological Diversity (2006). Access and Benefit Sharing. Available at: [Link].

7. Crawhall, N. et al. (2016). An Introduction to integrating African Indigenous and Traditional Knowledge in National Adaptation Plans, Programmes of Actions, Platforms and Policies. Capetown: IPACC. Available at: [Link].

8. Davis, S.H. (1993, April). The World Bank and Indigenous Peoples. (Conference Paper on Human rights), University of Denver Law School, Denver Colorado. Available at: [Google Scholar], [Link].

9. Debnath, Debashis (1992). Tribal Development and Political Institution: A Micro Study in West Bengal, Journal of the Indian Anthropological Society, 27(2), 175-180. Available at: [Google Scholar], [Link].

10. FAO (2010). FAO Policy on Indigenous and Tribal Peoples. Available at: [Google Scholar], [Link].

11. Forest People Programme (2013, April 29). African Development Bank set to introduce Indigenous Peoples Standard for the first time. Available at: [Link].

12. Forest People Programme (2020). International Alliance of Indigenous and Tribal Peoples of the Tropical Forests (IAITPTF). Available at: [Link].

13. Ford, J.D., Maillet, M., Pouliot, V., Meredith, T., Cavanaugh, A., \& IHACC Research Team (2016, December). Adaptation and Indigenous peoples in the United Nations Framework Convention on Climate Change. Climatic Change, 139(3), 429-443. Available at: [CrossRef].

14. Gawas, Vijay M. (2017, July). Analysis of the beneficial provisions of constitutional fifth schedule for tribal development. International Journal of Law, 3(4), 248-253. Available at: [Link].

15. Global Forest Coalition (2020, September 3). 15 years of REDD+: Has it been worth the money? Available at: [Link].

16. Global Forest Coalition (2020). GFC Annual Report 2019: Forest Protection through rights -based Action and Advocacy. Available at: [Link].

17. Griffiths, Tom (2005, July). Indigenous Peoples and the World Bank: Experiences with participation. Forests People Programme. Available at: [Google Scholar], [Link].

18. Harry, Debra \& Kaneha, L.M. (2006). Asserting Tribal Sovereignty over Cultural Property: Moving Towards Protection of Genetic Material and Indigenous Knowledge. Seattle Journal for Social Justice, 5(1), 1-25. Available at: [Link].

19. ILO (2020). Implementing the ILO Indigenous and Tribal Peoples Convention no-169: Towards an inclusive sustainable and just future. Available at: [Link].

20. Indigenous Peoples Council on Bio-colonialism (2006). The BS in Access and Benefit Sharing (ABS): Critical Questions for Indigenous Peoples. Available at: [Link].

21. IWGIA (2020). IWGIA Annual Report 2019. Available at: [Link].

22. Knuth, Lidija (2009). The right to adequate food and indigenous peoples: How can the right to food benefit indigenous peoples? FAO. Available at: [Link].

23. Mahapatra, Biswajit (2015, January). Traditional Tribal Institutions and Inclusive Development: Perspectives on Empowerment and Mobilisation. In Gassah and Thomas (Eds.), Democracy and Development in India's North East Challenges and Opportunities. New Delhi: Bookwell. (pp 363-373). Available at: [Link].

24. Mander, Harsh (2020). Tribal Development Policy in India. (Working Paper). New Delhi: Centre For Equity Studies. pp. 1-43. Available at: [Link]. 
25. Miller, Robert J. (2008). Inter-Tribal International Treaties for American Indian Economic Development. Lewis \& Clark Law Review, 12(4), 1103-1135. Available at: [Link].

26. Nanjunda, D.C., \& Dinesha, P.T. (2011, September). Role of Non-Governmental Organisation (NGOs) interventions on tribal health: Some innotations from grass root level. International NGO Journal,6(9),193196. Available at: [CrossRef].

27. Sarmah, Jayanta Krishna (2007). Role of Non-Governmental Organisation For Tribal Development and Social Welfare. The Indian Journal of Political Science, 66(3), 533-546. Available at: [CrossRef].

28. Survival International. (2017, May 19). Survival International-The movement for tribal people. Available at: [Link].

29. Thamminaina, Apparao (2018, June). Catalysts but not Magicians: Role of NGOs in the Tribal Development. Sage Open, 1-7. Available at: [CrossRef].

30. UNDP (2015, May 25). Concept Note: Supporting Meaningful Participation of Indigenous. Available at: [Link].

31. Peoples and Local Communities in UNFCCC COP 21 in Partnership with the International Indigenous Peoples Forum on Climate Change (IIPFCC) (draft of 25 May 2015). Available at: [Link].

32. UNFCCC (2018, December 10). COP24 Strengthens Climate Action of Local Communities. Available at: [Link]. 